\section{Tjaša Mohar \\ Tomaž Onič}

University of Maribor, Slovenia
2021, Vol. 18 (1), 125-137(222)

revije.ff.uni-lj.si/elope

https://doi.org/10.4312/elope.18.1.125-137

UDC: 81'255.4:821.111(71).09-1Atwood M.=163.6

\title{
Margaret Atwood's Poetry in Slovene Translation
}

\begin{abstract}
Margaret Atwood is undoubtedly the most popular Canadian author in Slovenia, with eight novels translated into Slovene. Although this prolific author also writes short fiction, poetry, children's books, and non-fiction, these remain unknown to Slovene readers, at least in their own language. Atwood has published as many poetry collections as novels, but her poetry is inaccessible in Slovene, with the exception of some thirty poems that were translated and published in literary magazines between 1999 and 2009. The article provides an overview of Atwood's poetry volumes and the main features of her poetry, as well as a detailed overview of Atwood's poems that have appeared in Slovene translation, with the names of translators, titles of poetry collections, dates of publication, and names of literary magazines. This is the first such overview of Slovene translations of Atwood's poetry. Additionally, the article offers an insight into some stylistic aspects of Atwood's poetry that have proven to be particularly challenging for translation.
\end{abstract}

Keywords: Margaret Atwood, Canadian Literature, Poetry, Literary Translation, Stylistics

\section{Poezija Margaret Atwood v slovenskem prevodu}

\section{IZVLEČEK}

Margaret Atwood je nedvomno najpopularnejša kanadska avtorica v Sloveniji; v slovenščini je doslej izšlo osem njenih romanov. Čeprav poleg romanov piše tudi kratko prozo, poezijo, knjige za otroke in neleposlovna dela, jo slovenski bralci poznajo skoraj izključno kot avtorico romanov. Njen bogat opus obsega prav toliko pesniških zbirk kot romanov, a njena poezija slovenskim bralcem ostaja nedostopna, z izjemo tridesetih pesmi izpod peres več prevajalcev, ki so se od leta 1990 do leta 2009 pojavljale v različnih literarnih revijah. Članek najprej predstavi pregled avtoričinih pesniških zbirk in omeni njihove glavne značilnosti, nato podrobno popiše pesmi, ki so doslej izšle v slovenskem prevodu, z navedbo prevajalcev, naslovov pesniških zbirk, letnic objav pesmi in literarnih revij, kjer so prevodi izšli - gre za prvi pregled v slovenščino prevedenih pesmi Margaret Atwood. Članek ponudi še vpogled v nekatere slogovne značilnosti avtoričine poezije, ki predstavljajo še posebej velik prevajalski izziv.

Ključne besede: Margaret Atwood, kanadska književnost, poezija, književno prevajanje, stilistika 


\section{Introduction}

There are not many world-famous authors who write across such a variety of genres as Margaret Atwood. Although Atwood has published as many poetry collections as novels, poetry is not what she is best known for internationally. Besides the highly acclaimed novel The Handmaid's Tale and its recent sequel The Testaments, Atwood's most read books include novels such as Surfacing, Lady Oracle, The Blind Assassin, Oryx and Crake, The Year of the Flood, and The Penelopiad, all of which have been translated into Slovene. In addition to novels and volumes of poetry, her rich bibliography covers several collections of short fiction, books of non-fiction, including those of literary criticism, then children's books and graphic novels, as well as a few television scripts and a theatre play.

Atwood's writing has been classified by various scholars as well as the media as feminist, ecofeminist, dystopian, or as speculative fiction - the later denomination being preferred by Atwood herself to science fiction (Atwood 2011, 5-6). Her short fiction pieces often escape classification; they can neither be classified as short stories, nor as essays or prose poems. Michelle Gadpaille $(2018,21)$ calls these "slipstream" fiction, owing to their generic flexibility.

This article focuses on Atwood's poetry and its representation in Slovene translation. Although none of Atwood's poetry volumes has been translated into Slovene, individual poems from a great number of her works have appeared in Slovene translation in various literary magazines. The article first gives an outline of Atwood's poetry collections and describes some features of her poetry, then it provides a detailed overview of Atwood's poems translated into Slovene so far, with an insight into some stylistic aspects of these translations.

\section{Poetry, One of Atwood's Many Genres}

Atwood's poetic opus consists of eighteen volumes of poetry, including collected works. She published her first volume of poetry, The Circle Game, in 1966, which earned her the Governor General's Award, Canada's highest literary award (see Margaret Atwood's Official website). This was followed by The Animals in That Country (1969), The Journals of Susanna Moodie, and Procedures for Underground (both 1970). According to Lothar Hönnighausen (2000, 102), The Journals of Susanna Moodie, which recalls frontier women, is among Atwood's most popular poetry collections. It represents "literary heritage for a country short on literary ancestors - particularly foremothers" (Onič, Gadpaille, Blake and Mohar 2020, 40). In the 1970s, Atwood published four volumes of poetry: Power Politics (1971), You Are Happy (1974), Selected Poems (1976), and Two-Headed Poems (1978). Hönnighausen argues that You Are Happy marks a break from Atwood's early poetry, which often displayed malicious wit, and sometimes even "grotesque pop art" $(2000,107)$. Two volumes of poetry followed in the 1980s, Two Stories (1981) and Interlunar (1984). True Stories consists of poems that draw "stark portraits of women's abuse and pain" (Slettedahl MacPherson 2010, 107), which Atwood learned of during her work with Amnesty International (Hönnighausen 2000, 10-11). Interlunar features Biblical imagery and poems about mythic figures, most of which are reformulated (Slettedahl MacPherson 2010, 108). In 1986 Atwood published her second volume of collected works, Selected Poems II: Poems Selected and New, 19761986, which was followed by Selected Poems 1966-1984 (1990), and Margaret Atwood Poems 
1965-1975 (1991). In the next volume, Morning in the Burned House (1995), and in the compilation Eating Fire: Selected Poems 1965-1995 (1998), which also includes new poems, Atwood retreats "from overt mythologizing to deceptively domestic scenes" (Onič et al. 2020, 40). Another compilation, Selected Poems 1965-1995, was published in 1998. Domestic imagery reappears in Atwood's penultimate volume, The Door (2007). Some poems in this collection appear to be autobiographical (Slettedahl MacPherson 2010, 108). Atwood's most recent volume of poetry was published in 2020, titled Dearly. In her review of the book in The Guardian, Kate Kellaway (2020) writes that the volume, which Atwood dedicated to her partner Graeme Gibson Green, "is a reckoning with the past that comes from a place of wisdom and control".

Apart from these eighteen poetry collections, Atwood's official website maintains another list of poetry publications categorized as "Art \& Small Press Editions". Various sources, however, even some approved by Atwood, classify some titles from that list among the "regular" poetry collections, such as Double Persephone (1961), Notes Towards a Poem That Can Never Be Written (1981), or Snake Poems (1983).

For example, the front matter of her most recent poetry collection Dearly lists Double Persephone under the "Poetry" heading. Between The Circle Game and The Animals in That Country, three more small press collections were published: Kaleidoscopes Baroque: a poem (1965), Talismans For Children (1965), and Speeches For Doctor Frankenstein (1966), and about a decade later the poem "Marsh, Hawk" (1977).

It is a challenge to describe Atwood's poetry in only a few words, for it is extremely diverse - like her other writings. Hönnighausen describes Atwood's poems as "entries into a kind of artistic logbook", and her writing of poetry like an "irresistible, ongoing process of perception, reflection, and aesthetic organization" (Hönnighausen 2000, 97). Branko Gorjup (2006, 130) agrees with Sherrill Grace that Atwood's work contains "'violent duality' of oppositional forces"; however, he believes that Atwood also shows how to transcend this duality. $\mathrm{He}$ further argues that physical and psychological space, and "the mapping of the world and the psyche" have a central place in Atwood's poetry $(2006,130)$. As regards the themes, Slettedahl MacPherson argues that the "problematic relationship between the sexes" is a recurring theme in all Atwood's oeuvre; however, she also spotlights Atwood's comic, ironic voice $(2010,104)$. The author further argues that Atwood is primarily a "free-verse poet", and that by balancing vision and voice, Atwood creates "intellectually rich poems" that consist of only a few lines (Slettedahl MacPherson 2010, 104). Atwood's poems often only appear to be simple, and "a clear voice leading the reader through imagery to a place of discovery, and then, just as calmly, snatching the discovery away" (Onič et al. 2020, 40).

\section{Segments of Atwood's Oeuvre in Slovene Translation}

None of Margaret Atwood's books of poetry have been published in Slovene as an integral collection; instead, the translations of individual poems have been published in Slovene literary and poetry journals. So far, as many as 40 poems have been translated by six different translators. They were published on seven different occasions in four journals and on one website. Ten of these poems, which were published on the Airbeletrina website are, 
unfortunately, no longer available. All Slovene translations of Atwood's poetry appeared between 1990 and 2009, which seems late considering that Atwood's first poetry collections came out in the 1960s, and by 1990 she had published more than a dozen. However, the delay with which Atwood's work began to trickle into Slovene does not only refer to her poetry. The first literary work by Atwood was only translated into Slovene in 1987, almost three decades after the beginning of the author's prolific writing career. This was the novel Lady Oracle (Slov. Preročišce) , which Atwood published in 1976.

The first Slovene translations of Atwood's poetic oeuvre were two poems published in 1990 in the literary journal Mentor: mesečnik za vprašanja literature in mentorstva, a monthly addressing the issues of literature and mentorship. The poems, "A painting of one location on the plain" from the collection Interlunar (1984) and an untitled poem ("The accident has occurred...") from Power Politics (1971), were included in a five-page essay "Potovanje brez konca na obzorju" (Engl. "A Journey No End at the Horizon") that presented the author's life and work; it also included translations of three pieces of short fiction, "The Page", "Murder in the Dark", and "Horror Comics", all from the collection Murder in the Dark (1983). The two poems and three pieces of short fiction were translated by Staša Grahek, who also wrote the accompanying text. The arrangement of the five pieces as a first taste of Atwood, complemented by short commentaries, seemed appropriate, since this Canadian author was still relatively little known to the non-English speaking Slovene audience at that time.

In 1997, the literary journal Dialogi published two poems, "Notes from Various Pasts" and "This is a Photograph of Me" from Atwood's early collections The Animals in That Country (1968) and The Circle Game (1964), respectively. These two poems formed part of a larger section on modern Canadian poetry which included translations of poems by several other Canadian poets: Milton Acorn, George Bowering, Al Purdy, John Newlove, and Bill Bisset. All sixteen poems in the selection were translated by Marcello Potocco, who also contributed brief footnotes containing useful information about the authors, as well as an essay outlining the development of anglophone Canadian poetry from the beginning of European settlement to the then present (cf. Potocco 1997). In the introduction, Potocco explains that the primary purpose of his essay is to extend the readers' knowledge of Canadian poetry beyond a handful of famous authors, among which he counts Margaret Atwood.

Three years later, the same journal (Dialogi) published an additional six Atwood poems, which were also translated by Marcello Potocco. This selection reaches back to Atwood's early collections and demonstrates the intention of being representational: while "After the Flood, We" and "Journey to the Interior" belong to The Circle Game (1964), the collection already represented in the previous Dialogi selection, the other four poems, "Further Arrivals", "Procedures for Underground", "They are hostile nations", and "November" are from four different and chronologically consecutive collections: The Journals of Susanna Moodie (1970), Procedures for Underground (1970), Power Politics (1971), and You Are Happy (1974). In a long final footnote, the translator explains that he intentionally selected poems from the author's earlier collections, since in those "Atwood emerges in her most distinctive light: somewhat surreal, with the central theme of the persona split between creating a (Platonist) pattern - a centre, and a chaotic outer world"1 (Potocco 2000, 90).

The footnote is written in Slovene; the quotation translated by T.O. 
Atwood's poems next appeared in Slovene translation in 2007. The literary journal for poetry Rp./Lirikon published eight poems by two translators: "A Sad Child", "February", and "Manet's Olympia" by Marjana Karer; and "You Fit into Me", "Postcard", "Bored", "Siren Song", and "Night Poem" by Urška Zupanec. The first three are from the Morning in the Burned House (1995) collection, and each of the other five comes from a different collection: Power Politics (1971), Morning in the Burned House (1995), and You Are Happy (1974), which have been previously represented in Slovene translation, while True Stories (1981) and Two-headed Poems (1978) have not. Zupanec added the English originals to the translated poem titles. Moreover, in the case of the typically Atwoodian four-lined poem "You Fit into Me...", she preserved the original version - it appears on the same page, right next to the translation. This is rather unusual - except in the cases of bilingual editions - yet in this case it makes considerable sense, since the translatability of this poem, which will be discussed in the following section, is extremely low. The eight poems translated by Karer and Zupanec received a nomination for the local literary prize Lirikonov zlat (Engl. Lirikon's golden coin), which is awarded for achievements in 21 st-century poetry translation from or into Slovene (Ustanova Velenjska knjižna fundacija 2001-2020). The translators are free to choose the material for translation and submit it to an open call.

In the same year, 2007, another selection of 10 poetry translations appeared on the literature distribution and publication website Airbeletrina, supported by the Beletrina publishing house, the Slovene Ministry of Culture, and the Slovene Book Agency. The poems were translated by Barbara Jurša and were all selected from the collection Power Politics (Barbara Jurša, email to author, February 17, 2021). Unfortunately, these poems are no longer available on-line.

The most recent publication of Atwood's poems in Slovene translation appeared in the literary journal Poetikon in 2009. This was a selection of twelve poems from her collection The Door (2007). The translator Barbara Jurša seemed to have moved away from the apparent previous tendency of attempting to represent the poet's oeuvre by selecting poems from various collections, and towards an approach more focused on a single collection. Moreover, when the translated poems were published in 2009, Jurša chose Atwood's most recent poetry volume. The translations come with a brief foreword listing Atwood's literary and non-literary achievements; for example, her presidency of the Canadian PEN, and her membership in Amnesty International and in the Canadian Green Party (Jurša 2009, 140).

From this brief overview and Table 1, which compiles data regarding Atwood's poetry translations into Slovene, we can see that eleven major collections of her poetry are represented in Slovene - in some cases with only a single poem, while in the case of The Door, as many as twelve translated poems are available to the Slovene reader. This imbalance seems to reflect the strategy governing the selection of the poems to be translated: The Door, as a recent collection, dominates in terms of the number of translated poems, while the earlier poems are minimally, yet consistently sampled. The translations of the early poems offer an insight into the poet's early style, while also making the reader aware of the existence of the early collections, testifying to Atwood's extensive poetic oeuvre. Among the 18 poetry collections listed on Atwood's official website, six mostly provide selections of poems previously published in earlier collections. These figures do not include the collections with less impact that Atwood's official site lists as 
"Art \& Small Press Editions" - these are collections such as Double Persephone (1961), Speeches For Doctor Frankenstein (1966), Notes Towards a Poem That Can Never Be Written (1981), Snake Poems (1983), etc. - but from among the remaining 12 collections, 11 are represented in Slovene translation; the most recent collection Dearly, which was published only in 2020, has so far not been translated. This means that from this angle, Atwood's poetry is adequately represented in Slovene, although given the rank and capacity of this Canadian literary giant, pursuing further translations of her poetry would be most welcome.

TABLE 1. Margaret Atwood's poems in Slovene translation, arranged by date of publication in Slovene literary journals.

\begin{tabular}{|c|c|c|c|}
\hline $\begin{array}{l}\text { Translator, } \\
\text { Journal, Year of } \\
\text { Publication } \\
\end{array}$ & $\begin{array}{l}\text { Poetry Collection, } \\
\text { Year of Publication }\end{array}$ & Poem Title (English) & Poem Title (Slovene) \\
\hline \multirow{2}{*}{$\begin{array}{l}\text { Staša Grahek, } \\
\text { Mentor, } 1990\end{array}$} & Interlunar, 1984 & $\begin{array}{l}\text { A Painting of One } \\
\text { Location on the Plain } \\
\end{array}$ & $\begin{array}{l}\text { Slikanje prizorišča } \mathrm{v} \\
\text { naravi }\end{array}$ \\
\hline & Power Politics, 1971 & (untitled) & \\
\hline \multirow{2}{*}{$\begin{array}{l}\text { Marcello Potocco, } \\
\text { Dialogi, } 1997\end{array}$} & $\begin{array}{l}\text { The Animals in That } \\
\text { Country, } 1968 \\
\end{array}$ & \begin{tabular}{|l|} 
Notes from Various \\
Pasts
\end{tabular} & \begin{tabular}{|l|} 
Zapiski iz raznih \\
preteklosti
\end{tabular} \\
\hline & $\begin{array}{l}\text { The Circle Game, } \\
1964\end{array}$ & $\begin{array}{l}\text { This Is a Photograph } \\
\text { of Me }\end{array}$ & $\begin{array}{l}\text { Na tej fotografiji sem } \\
\text { jaz }\end{array}$ \\
\hline \multirow{6}{*}{$\begin{array}{l}\text { Marcello Potocco, } \\
\text { Dialogi, } 2000\end{array}$} & \begin{tabular}{|l} 
The Journals of \\
Susanna Moodie, \\
1970 \\
\end{tabular} & Further Arrivals & Naslednji prihodi \\
\hline & $\begin{array}{l}\text { Procedures for } \\
\text { Underground, } 1970\end{array}$ & \begin{tabular}{|l|} 
Procedures for \\
Underground \\
(Northwest Coast) \\
\end{tabular} & $\begin{array}{l}\text { Pravila za podzemlje } \\
\text { (Severozahodna obala) }\end{array}$ \\
\hline & $\begin{array}{l}\text { The Circle Game, } \\
1964\end{array}$ & After the Flood, We & Po poplavi, midva \\
\hline & $\begin{array}{l}\text { The Circle Game, } \\
1964\end{array}$ & Journey to the Interior & Potovanje v notranjost \\
\hline & Power Politics, 1971 & They are hostile nations & To so sovražni narodi \\
\hline & You Are Happy, 1974 & November & November \\
\hline \multirow{3}{*}{$\begin{array}{l}\text { Marjana Karer, } \\
\text { Rp./Lirikon 21, } 2007\end{array}$} & \multirow{3}{*}{$\begin{array}{l}\text { Morning in the } \\
\text { Burned House, } 1995\end{array}$} & A Sad Child & Žalosten otrok \\
\hline & & \begin{tabular}{|l|} 
February \\
\end{tabular} & Februar \\
\hline & & Manet's Olympia & Manetova Olimpija \\
\hline \multirow{5}{*}{$\begin{array}{l}\text { Urška Zupanec, } \\
\text { Rp./Lirikon 21, } 2007\end{array}$} & Power Politics, 1971 & You Fit into Me & $\begin{array}{l}\text { You Fit into Me; Pašeš } \\
\text { vame }\end{array}$ \\
\hline & True Stories, 1981 & Postcard & Razglednica \\
\hline & \begin{tabular}{|l|} 
Morning in the \\
Burned House, 1995
\end{tabular} & Bored & Dolgčas \\
\hline & You Are Happy, 1974 & Siren Song & Spev siren \\
\hline & $\begin{array}{l}\text { Two-headed Poems, } \\
1978\end{array}$ & Night Poem & Nočna pesem \\
\hline $\begin{array}{l}\text { Barbara Jurša, } \\
\text { AirBeletrina, } 2007\end{array}$ & Power Politics, 1971 & \multicolumn{2}{|c|}{$\begin{array}{l}10 \text { poems or poem sections, currently } \\
\text { unavailable }\end{array}$} \\
\hline
\end{tabular}




\begin{tabular}{|c|c|c|c|}
\hline \multirow{12}{*}{$\begin{array}{l}\text { Barbara Jurša, } \\
\text { Poetikon, } 2009\end{array}$} & \multirow{12}{*}{ The Door, 2007} & Gasoline & Bencin \\
\hline & & Heart & Srce \\
\hline & & The Singer of Owls & Sovji pevec \\
\hline & & Secrecy & Skritost \\
\hline & & It's Autumn & Jesen je \\
\hline & & $\begin{array}{l}\text { Nobody Cares Who } \\
\text { Wins }\end{array}$ & $\begin{array}{l}\text { Nikomur ni mar, kdo } \\
\text { zmaga }\end{array}$ \\
\hline & & War Photo & Vojna fotografija \\
\hline & & War Photo 2 & Vojna fotografija 2 \\
\hline & & Possible Activities & Možne dejavnosti \\
\hline & & Ten O'Clock News & Poročila ob desetih \\
\hline & & White Cotton T-Shirt & Bela bombažna majica \\
\hline & & $\begin{array}{l}\text { Enough of These } \\
\text { Discouragements }\end{array}$ & $\begin{array}{l}\text { Dovolj je te } \\
\text { malodušnosti }\end{array}$ \\
\hline
\end{tabular}

\section{Stylistic Aspects of Translating Atwood}

Translating Atwood's poetry is by no means an easy task, for its apparent simplicity is deceptive. The multi-layered interpretive potential is frequently complemented by playful linguistic creativity, unexpected deception, and original punning, all of which pose problems for the translator. A perfect example of several of these characteristics is the opening poem from Atwood's collection Power Politics, "You Fit into Me". The four-liner is not even long enough to possess an independent title, yet the objective possibilities for its translation are extremely low; it cannot be rendered into Slovene without losing its double meaning, its recursive structure as well as its linguistic playfulness:

you fit into me

like a hook into an eye

a fish hook

an open eye (Atwood 1972)

Despite its brevity, the poem has two distinct parts, the duality of which Slettedahl MacPherson $(2010,105)$ relates to the binary concept of innocence and experience. The first part is built around a central simile, in fact, an ordinary cliché: two people fitting together like a hook into an eye is a rather non-poetic collocation suggesting a perfect match. A hook and an eye are two parts of a closure, usually metal or hard plastic, used for fastening clothes together - so there is nothing unusual about this plain, yet significant simile. In the second part, however, the unsuspecting reader realizes $s /$ he has been deceived: by adding a single adjective to each of the items in the phrase, the poet thwarts the comfortable interpretation of an ordinary scene and forces the reader to re-conceptualize their perception entirely. A fishhook and an open eye twist the initial simile and imply an extremely painful relationship that with its blunt and straightforward choice of words creates a powerful and physically painful tactile image for the reader. 
The main translation challenge in this poem is to preserve the twisted simile, since it stands prominently at the centre of the poem, paving the way for the leading interpretations. The translator into Slovene faces an unbridgeable divide, since the central concept of the "hook and eye" does not have a corresponding bipolar counterpart in Slovene; it can be done either with the help of a description, or it can be translated "per partes", as has been done in the existing Slovene translation ("trnek", "oko"), but the syntagm does not carry the single unified reference to the garment-clasping equipment as it does in English. Moreover, both items in the phrase - which does not function in an idiomatic way - spoil the upcoming twist upon their first mention:

pašeš vame
kot trnek v oko
ribiški trnek
odprto oko (Atwood 2007, 126)

The Slovene translation of the "hook ("trnek") can only mean "fishhook" ("ribiški trnek"), while the "eye" ("oko") will be perceived as a human eye. In theory, "oko" does have other dictionary meanings, like the sprouting place on a potato ("oko krompirja") or grapevine ("oko vinske trte"), but no context is created to evoke an alternative reading, similar to the "hook and eye" notion in the original that could deceive the reader. In fact, Slovene would be more prone to use a different bodily (dead) metaphor, i.e., "uho" ("an ear") to refer to a ring-like metal, wooden or plastic object that takes a hook-like counterpart, an everyday example being the eye of a needle, which in Slovene is "the ear of a needle" ("sivankino uho"). This consequently disables many interpretative dimensions that in English may be perceived as a given.

This brings us to another frequently noted characteristic of Atwood's poetry that presents a translation challenge: her elliptical discourse creates ambiguity and is, according to Slettedahl MacPherson $(2010,106)$, often responsible for the elusiveness of definite interpretation. Even though it is not an axiomatically unresolvable element, it still requires a linguistically skilled translator who is aware of the interpretative openness of the original and committed to preserving the feature in the translation. This aspect can be observed in the second part of "You Fit into Me"; and is further illustrated by the poem "Heart" from the collection The Door. While the opening consists of short but still full sentences, Lines 4, 5 and the beginning of Line 6 are phrases and sentence fragments:

Some people sell their blood. You sell your heart.

It was either that or the soul.

The hard part is getting the damn thing out.

A kind of twisting motion, like shucking an oyster,

your spine a wrist,

and then, hup! it's in your mouth. /.../ (Atwood 2007)

The absence of conjugated verbs moves the text away from a connected narrative and creates a fragmented discourse with gaps, reminiscent of leaps in the stream of thought. This is a 
stylistic element of discourse that significantly influences perception and should therefore be preserved in translation as much as possible. According to Mozetič (2004), translators into Slovene are frequently tempted to fill these gaps and create a smooth flow of thought for the reader, ${ }^{2}$ as is partly the case in the translation of "Heart":

Nekateri prodajajo svojo kri. Ti prodajaš svoje srce.

Lahko si izbiral: bilo je to ali duša.

Gre za nekakšno ukrivljeno gibanje, kot pri luščenju ostrig,

tvoja hrbtenica oblikuje zapestje

in nato je, hop!, srce v tvojih ustih. /.../ (Atwood 2009, 142)

In this excerpt, there are several additions that Mozetic (2004) calls explicitation. The addition of the verb "gre za" ("it is about..." or "it is a...") explicitates the nominal phrase in the original. Similarly, the following line contains the verb "oblikuje" ([your spine] "shapes" [the wrist]), which also deprives the Slovene reader of the task of connecting the loose items by themselves. In the last line of the excerpt, the translation adds the noun "srce" ("heart"), while in the original, the poet uses only the pronoun "it", which Slovene can accommodate in the verb. A particularly notable addition is the sentence "Lahko si izbral:" ("You had a choice:"), which, apart from explicitation, opens another translation issue that is not limited to Atwood's poetry but appears frequently in translation from English into Slovene: this is the speaker's (or addressee's) gender, which English finds easier to retain unspecified or concealed than Slovene. While predicative adjectival phrases and tense-forming past participles in English do not disclose the gender, the translator needs to choose between the masculine or the feminine forms in Slovene, thus committing to the speaker's gender. The translator of the selected poems from The Door often chooses the feminine forms, which seems a natural choice, considering that some poems in this volume have a strong autobiographical tone, and the voice of the persona is easily equated with that of the poet. In the explicative addition "Lahko si izbral", however, the translator chose the masculine form, which can be read as the generic "ti" (literally "you", in formal English frequently represented as "one": "one could choose"), meaning it is masculine in form but can refer to men and women. Although this masculine form should not be a distraction, a simpler solution in this case could be to eliminate the addition. Additions or, rather, explicitations also appear at the end of the poem:

$/ \ldots /$ and you stand listening to all this

in the corner, like a newly hired waiter,

your diffident, skilful hand on the wound hidden

deep in your shirt and chest,

shyly, heartless. (Atwood 2007)

Explicitation may not be entirely unfavourable; Gadpaille and Zupan (2020) comment on explicitation bridging the text and paratext in Shakespeare's historical plays. 
/.../ ti pa stojiš v kotu in poslušaš

vse to kot na novo najet natakar

in tvoja plaha, spretna dlan počiva na rani, skriti

globoko v tvoji srajci in tvojih prsih,

stojiš tam, sramežljivo in brez srca. (Atwood 2009, 142)

The antepenultimate line contains the added predicator "počiva" ([skilful hand] "rests" [on the wound]), while the last line contains two such cases of explicitation: one is the added, in fact, loosely repeated "stojiš tam" ("you stand there"), and the other is the added conjunction before the last item, which changes "shyly, heartless" into "shyly and heartless". The latter is particularly problematic, since it tends to add a certain closure to the poem, which in the original ends abruptly and with a sense of incompletion, which is in line with the persona's expectation of further criticism. This effect is further backed by the brevity of the line, as well as the asyndetonic quality that can leave the ending open or incomplete. The Slovene translation, instead, prolongs the line and provides a closure suggesting that no further damage can be inflicted on the speaker. Here is an alternative translation by the authors of this paper that better preserves these aspects and thus the style of the original, which is possible by adding some minor grammatical explication (added dashes for the imbedded interjection):

$$
\begin{aligned}
& \text { /.../ ti pa stojiš v kotu in poslušaš } \\
& \text { vse to kot na novo najeti natakar - } \\
& \text { tvoja plaha, spretna dlan na rani, skriti } \\
& \text { globoko v tvoji srajci in v tvojih prsih -, } \\
& \text { sramežljivo, brez srca. }
\end{aligned}
$$

A similar issue can be seen in at least two places in the poem "War Photo" from The Door:

/.../ One leg extended, the other fixed, foot pointed

towards the knee, the arm flung overhead, the hand

relaxed into a lovely gesture

a dancer might well study for years

and never attain. /.../ (Atwood 2007)

The existing Slovene translation adds the conjugated verbs "to have" and "to be" in the first line, turning elliptical sentences, i.e., fragments, into clauses, while preserving the fragments in lines three and four:

$$
\begin{aligned}
& \text { /.../ Eno nogo ima raztegnjeno, drugo pokrčeno, stopalo je } \\
& \text { obrnjeno h kolenu, roka zalučana nad glavo, dlan } \\
& \text { sproščena v ljubko kretnjo, } \\
& \text { ki bi se je plesalka učila lahko učila več let } \\
& \text { in je nikoli dosegla. / ... ( Atwood 2009, 147; emphasis added by the authors) }
\end{aligned}
$$


Backtranslation of the first two lines:

/.../ She has one leg extended, the other fixed, her foot is

pointed towards the knee /.../

Again, to more closely preserve the author's style, the elliptical syntax should be also preserved in the first line of the translation, for instance:

\section{/.../ Ena noga iztegnjena, druga pokrčena, stopalo}

obrnjeno h kolenu /.../

Gadpaille $(2014,174)$ points out Atwood's use of irony in her book of literary criticism titled Survival, "which is not always detected or appreciated", meaning that readers, particularly European ones, tend to take her too seriously. Translators therefore have a difficult task: they need to both detect the irony and preserve it. Irony and black humour also feature in Atwood's latest poetry volume, Dearly, although the recurring themes of the poems are aging and death. Let us look at a poem from this collection titled "At a Translation Conference", which aligns with our theme. As Atwood explains, the inspiration for this poem came from her visit to Japan, where she learned that "the word for 'No' was too abrupt in Japanese for women to say - it sounded rude - but there were ways of saying 'No' without using the actual word, and they were understood" (Buna 2020). This is how the poem begins:

\section{/.../ In our language}

we have no words for he or she

or him or her.

It helps if you put a skirt or tie

or some such thing

on the first page.

In the case of a rape, it helps also

to know the age:

a child, an elderly?

So we can set the tone.

We also have no future tense:

what will happen is already happening.

But you can add a word like Tomorrow

or else Wednesday.

We will know what you mean. /.../ (Atwood 2020, 66)

Beside irony and black humour, such as can be found in Lines 3-6 of the first stanza, or in Lines 4-6 in the third, there is also elliptical language in the second stanza, where the translator into Slovene might be tempted to use explicitation. Another translation challenge in this poem is the appearance of personal pronouns in the first stanza: while the English 
language distinguishes only between two cases (he/him; she/her), Slovene has six (for the masculine form, for example, "on/njega/njemu/njega/pri njem/z njim"), with the second and the fourth cases often being the same. The potential translation of "he/him" into Slovene as "on/njega" thus bypasses the other existing forms in Slovene. The instances of such relatively simple issues that tend to pose translation difficulties suggest that Atwood's latest poetry seems to confirm what has been previously established, i.e., that the simplicity of her poems is only apparent.

\section{Conclusion}

Although Margaret Atwood is by far the most famous Canadian author in Slovenia, this is mostly on account of her novels. Her poetry, on the other hand, together with her short fiction and non-fiction, is still relatively unknown to Slovene readers in their own language. This overview of Slovene translations of Atwood's poetry has shown that some poems from various collections have appeared in Slovene over the last thirty years, and while the penultimate collection, The Door, has had one-fifth of its poems translated and published in Slovene, the others are mostly represented by one or two. A stylistic analysis of some of the poems that have been translated revealed several issues that Slovene translators of Atwood's poetry face, such as grasping the multi-layered interpretive potential of her poems, preserving their often ambiguous elliptical discourse without recurring to explicitation, and preserving their black humour and irony. Owing to its implicit rather than explicit nature, poetry is more open to multiple interpretations and is therefore more challenging for translation than prose. Atwood has stressed this characteristic of poetry in a recent interview: "Poems do not assert. They explore. One of the things they explore is language. In a legal contract, you want all the words to have one meaning and one meaning only. In a poem, words often have several meanings" (2020). Pilar Somacarrera, the translator of Atwood's poetry volume Power Politics into Spanish, reveals that her approach to Atwood's poems was pragmatic rather than theoretical. It included a stylistic analysis of the poems and the reviewing of the existing criticism on the material; it also took into account the poems' political and feminist contexts as well as "the multiple readings that the poems could offer" (Somacarrera 2006). Somacarrera concludes that it is possible and necessary to translate Atwood into Spanish but that "snow must remain snow, ${ }^{3}$ that is the Canadian and feminist dimensions of her source text must reverberate in the Spanish versions" (2006). The reason why none of Atwood's poetry volumes has so far been published in Slovene is probably not the lack of translators willing to accept the challenge, for we have seen that there have been several up for the challenge, but more the ranking of poetry among literary genres and readers. If the novel is the queen among genres, poetry is only for gourmets, and those never reach the same ballpark, let alone outnumber the readers and buyers of longer prose, where the book market is rather small. And if poetry does get published, original poetry comes before translations. Fortunately, there are literary magazines, which are interested in publishing poetry (and short fiction), and it is thanks to these that Atwood's poetry has not been completely overlooked by the Slovene literary readership.

Somacarrera alludes here to section V from Atwood's poem "Two Headed Poems", in which the persona says that it is impossible to describe snow, "there could be no translation" (Atwood 1987, 29). 


\section{References}

Atwood, Margaret. 2020. Dearly. London: Chatto and Windus.

—. 2020. "The World We Think We See Is Only Our Best Guess: A Conversation with Margaret Atwood." Interview by M. Buna. Poetry Foundation, November 18, 2020. https://www.poetryfoundation.org /harriet-books/2020/11/the-world-that-we-think-we-see-is-only-our-best-guess-in-conversation-with -margaret-atwood.

—. 2013-2021. "Margaret Atwood." http://margaretatwood.ca/.

- 2011. In Other Worlds. New York: Double Day, Random House.

—. 2009. "Srce." Translated by Barbara Jurša. Poetikon V (25/26): 142.

—. 2009. "Vojna fotografija." Translated by Barbara Jurša. Poetikon V (25/26): 147.

—. 2007. "Pašeš vame." Translated by Urška Zupanec. Rp./Lirikon21 III (2+3): 126.

-. 2007. The Door. Toronto: McClelland \& Stewart.

—. 1987. Selected Poems II: Poems Selected \& New, 1976-1986. Boston: Houghton Mifflin.

-. 1972. Power Politics. Toronto: Anansi.

Gadpaille, Michelle. 2018. "Sci-Fi, Cli-Fi or Speculative Fiction: Genre and Discourse in Margaret Atwood's 'Three Novels I Won't Write Soon'.” ELOPE 15 (1): 17-28. https://doi.org/10.4312/elope .15.1.17-28.

—. 2014. "Thematics and Its Aftermath: A Meditation on Atwood's Survival." Primerjalna književnost 37 (3): 165-77.

Gadpaille, Michelle, and Simon Zupan. 2020. "Interpreting and Translating Shakespeare's Heraldic Terminology: 1 Henry IV and 2 Henry VI in Slovene." Annales, Series Historia et Sociologia: 28 (2): 309-25. https://doi.org/10.19233/ashs.2020.02.

Gorjup, Branko. 2006. “Margaret Atwood's Poetry and Poetics.” In The Cambridge Companion to Margaret Atwood, edited by Coral Ann Howells, 130-44. Cambridge: Cambridge University Press.

Hönnighausen, Lothar. 2000. “Margaret Atwood's Poetry 1966-1995.” In Margaret Atwood: Works and Impact, edited by Reingard M. Nischik, 97-119. Rochester: Camden House.

Jurša, Barbara. 2009. “Margaret Atwood.” Poetikon V (25/26): 140.

Kellaway, Kate. 2020. "Dearly by Margaret Atwood Review - The Experience of a Lifetime." The Guardian, November 23, 2020. https://www.theguardian.com/books/2020/nov/23/dearly-by-margaret-atwood -review-the-experience-of-a-lifetime.

Mozetič, Uroš. 2004. "Explicitation and Implicitation as Translation Universals and Their Occurrences in the Slovene Translations of Anglo-American Literary Texts." ELOPE 11 (2): 101-14. https://doi.org /10.4312/elope.11.2.101-114.

Onič, Tomaž, Michelle Gadpaille, Jason Blake, and Tjaša Mohar. 2020. "Margaret Atwood, World-Famous but Yet to Be Discovered by Many Slovene Readers." Acta neophilologica 53 (1/2): 33-47. https://doi .org/10.4312/an.53.1-2.33-47.

Potocco, Marcello. 1997. "Angleška kanadska poezija, problem identitete in mita." Dialogi 1-2: 90-97.

Slettedahl MacPherson, Heidi. 2010. The Cambridge Introduction to Margaret Atwood. Cambridge: Cambridge University Press.

Somacarrera, Pilar. 2005. “'How Can You Use Two Languages and Mean What You Say in Both?’: On Translating Margaret Atwood's Poetry into Spanish.” Traduction, terminologie, redaction 18 (1): 15781. https://doi.org/10.7202/014371ar.

Ustanova Velenjska knjižna fundacija. 2001-2020. “UVKF Official website.” http://uvkf.si/en/about-uvkf. 